\title{
Monetary policy and U.S. long-term interest rates: How close are the linkages?
}

\author{
Hakan Berument ${ }^{\mathrm{a}}$, Richard Froyen ${ }^{\mathrm{b}, *}$ \\ ${ }^{a}$ Bilkent University, Ankara, Turkey \\ ${ }^{\mathrm{b}}$ Department of Economics, CB\#3305, University of \\ North Carolina, Chapel Hill, \\ NC 27599-3305, United States
}

Received 1 August 2006; received in revised form 5 November 2007; accepted 19 November 2007

\begin{abstract}
The effect of monetary policy on long-term interest rates has been a question of interest in recent years. A number of papers, relying on single-equation estimation techniques, have presented evidence that long-term interest rates exhibit sizable and significant responses to unanticipated changes in the Federal Reserve's target federal funds rate. This paper examines these findings in light of conflicting findings from VAR studies, which indicate negligible effects of innovations in the federal funds rate on long-term rates. To address the issue we use a single-equation approach where unanticipated changes in the federal funds rate are measured as residuals from policy reaction functions. We also estimate VAR specifications, which incorporate information about the timing of changes in the Federal Reserve's target federal funds rate. Our single-equation estimates provide evidence of strong responses of long rates to unanticipated changes in the federal funds rate both for the Greenspan period and for a longer period back to the mid-1960s. It seems likely that estimated VARs for the post-1987 years are less successful in isolating monetary policy surprises than was the case for earlier years.

(C) 2007 Elsevier Inc. All rights reserved.
\end{abstract}

JEL classification: E43; E52; E58

Keywords: Monetary policy; Long-term interest rate

* Corresponding author. Tel.: +1 919966 5375; fax: +1 9199664986.

E-mail address: froyen@email.unc.edu (R. Froyen). 


\section{Introduction}

In 2006 the Financial Times called the question of why long-term interest rates were so low "the central economic problem of our time." Referring to the question of why long-rates failed to rise in the wake of a sustained increase in U.S. short-term rates, the Times declared that "The fortunes of millions rest in no small measure on the answer to this question." Journalistic exaggeration aside, the effect of monetary policy on long-term interest rates is a subject of considerable interest. Given current U.S. monetary policy procedures, this question reduces to that of how a change in the federal funds rate affects the yields on longer-term securities. A decade ago a reading of the literature would have indicated considerable doubt about even the direction of this effect. ${ }^{1}$ There was also a view that the size and persistence of the effect of the federal funds rate on longerterm yields would vary with economic conditions. ${ }^{2}$ The prevailing theory of the term-structure of interest rates, the expectations hypothesis, by itself provides little guidance about the effect monetary policy actions will have on longer-term interest rates: the nature of the effect depends on the way in which the policy action affects expected future short-term interest rates and risk premiums imbedded in long rates.

Research since 2000 has changed the situation. Studies by Kuttner (2001), Cochrane and Piazzesi (2002), Gurkaynak, Sack, and Swanson (2005a), Ellingsen and Söderström (2003), Ellingsen, Söderström, and Masseng (2004) and Beechey (2007) provide evidence that unanticipated changes in the federal funds rate have significant effects on U.S. interest rates at maturities as long as 10 or 30 years. Kuttner's estimates, for example, indicate that an unanticipated rise of one-percentage point in the federal funds target rate will increase the interest rate on a 10-year government security by 32 basis points and the rate on a 30 -year security by almost 20 basis points. If one accepts the expectations hypothesis concerning the term-structure of interest rates, it is unclear why current monetary policy actions should be affecting expectations of short-term rates so far in the future. These empirical results have led to theoretical explanations, the most common of these centering on the effect monetary actions have on market participants' perceptions of the Federal Reserve's information set and policy preferences, including their long-run target inflation rate.

But how strong is this evidence of sizable significant responses of longer-term interest rates to unanticipated changes in the federal funds rate? Two characteristics of the above cited empirical studies are: they deal with the post-1987 period and use single-equation econometric methodologies. A number of other studies of the relationship between the federal funds rate and long-term interest rates use a VAR methodology and look at a longer time period: Evans and Marshall (1998), Edelberg and Marshall (1996), and Berument and Froyen (2006). These studies do not find significant sustained effects of monetary policy on long-term interest rates. Evans and Marshall, for example, find that "a contractionary policy shock induces a pronounced positive but shortlived response of short-term interest rates. The response declines monotonically with maturity; long-term rates are virtually unaffected."

This paper addresses the discrepancy between results from the two types of studies. We pursue two lines of inquiry. First, there are questions about the ability of the VAR methodology to capture policy actions and particularly policy surprises. Market forecasters may adapt to changing

\footnotetext{
1 See Akhtar (1995) as well as the discussion and references in Berument and Froyen (2006).

2 Roley and Sellon (1995, p. 73), for example, state that "the relationship between policy actions and long-term rates is likely to vary over the business cycle as financial market participants alter their views on the persistence of policy actions."
} 
circumstances using information not incorporated in VARs. VARs have used monthly and quarterly data posing an identification problem alleviated by daily data used in single-equation studies. Finally, most VAR studies have focused on long sample periods and may fail to reflect recent changes in the transparency of Federal Reserve policy.

Alternatively, single-equation techniques fail to control for other factors that change contemporaneously with monetary policy. Single-equation studies may suffer from an omitted variable problem. Craine and Martin (2003) provide evidence that this is the case. Moreover, singleequation estimates are based on a small sample mostly from the 1990s. VAR estimates may better characterize the general response of long-term rates to monetary policy.

We proceed as follows. Section 2 reviews evidence from previous econometric studies of the relationship between the federal funds rate and longer-term interest rates. Section 3 presents the results of estimating VARs. These estimates serve as a base of comparison for our singleequation estimates. The VARs are also modified to incorporate information about the timing of changes in the Federal Reserve's target federal funds rate. In Section 4 we use a reaction function-based approach to measure monetary policy shocks and study their effects on longerterm interest rates. In Section 5 we consider the implications of our results for the question asked in the title: how close are the linkages between the federal funds rate and longer-term interest rates?

\section{Results of previous studies}

Table 1 summarizes some previous econometric research on the effects on longer-term interest rates of changes in the federal funds rate. The table reports results of single-equation and VARbased estimates. This section discusses the implications of these studies, as well as some others in the literature.

\subsection{Single-equation studies}

A difficulty facing researchers is that the Federal Reserve's operating target, the federal funds rate, is an endogenous variable. Some method must be used to isolate the effect of monetary policy actions on the funds rate. Moreover, anticipated and unanticipated policy actions have different effects; some method is needed to distinguish between the two types of policy actions. The studies in lines 1-3 of Table 1 address these problems. They use dates of changes in the Federal Reserve's target federal funds rate to isolate policy actions. A variety of methods of differentiating anticipated from unanticipated actions are used. Kuttner (2001), for example, used data from the federal funds futures market to measure market anticipations of policy actions. All three studies show substantial significant responses of interest rates at maturities of 10 and 30 years to changes in the federal funds rate.

Evidence of a significant response of long-term interest rates to changes in the monetary policycontrolled short-term rate has led to several lines of explanation. Romer (2001) and Romer and Romer (2000) suggest that a rise, for example, in the federal funds rate reveals a Federal Reserve forecast of higher inflation leading the market to predict higher future short-term interest rates. To explain the effect on interest rates at maturities as long as 30 years Gurkaynak et al. (2005a), Gurkaynak, Levin, and Swanson (2006), Beechey (2004) and Ellingsen et al. (2004) suggest that Federal Reserve policy moves reveal information about the central bank's long-term inflation target. Beechey (2007) provides evidence that movements in term premiums are important in explaining this response. 
Table 1

Estimated effect on longer-term interest rates from a $1 \%$ change in the federal funds rate

\begin{tabular}{|c|c|c|c|c|c|c|c|c|c|c|c|}
\hline & \multirow[t]{2}{*}{ Study } & \multirow[t]{2}{*}{ Time period } & \multicolumn{9}{|c|}{ Effect in percentage points on yield at maturity: ${ }^{\mathrm{a}}$} \\
\hline & & & Type & 3 months & 6 months & 1 year & 2 years & 3 years & 5 years & 10 years & 30 years \\
\hline 1 & Kuttner (2001) & 1989:6-2000:2 & SE & $0.79 *$ & $0.72 *$ & $0.72 *$ & $0.61 *$ & - & $0.48 *$ & $0.32 *$ & $0.19^{*}$ \\
\hline 2 & Ellingsen and Söderström $(2003)^{\mathrm{b}}$ & 1988:10-2000:12 & SE & - & - & 0.83 & 0.68 & - & 0.51 & 0.29 & 0.17 \\
\hline 3 & Cochrane and Piazzesi (2002) & 1984-2001 & SE & $0.62 *$ & - & $0.72 *$ & - & $0.67 *$ & - & $0.52 *$ & - \\
\hline 4 & Edelberg and Marshall (1996) ${ }^{\mathrm{c}}$ & 1947-1995 & VAR & - & 0.56 & 0.42 & - & 0.24 & - & 0.08 & - \\
\hline 5 & Berument and Froyen $(2006)^{\mathrm{d}}$ & $1987: 8-2002: 8$ & VAR & - & - & 0.13 & - & - & - & 0.05 & - \\
\hline 6 & Berument and Froyen (2006) & 1975:1-2002:8 & VAR & - & - & 0.23 & - & - & - & 0.09 & - \\
\hline 7 & Berument and Froyen (2006) & 1975:1-1979:9 & VAR & - & - & 0.43 & - & - & - & 0.14 & - \\
\hline 8 & Cook and Hahn (1989) & 1974:9-1979:9 & SE & $0.55^{*}$ & $0.54 *$ & $0.50^{*}$ & - & $0.29 *$ & $0.21 *$ & $0.13 *$ & $0.10 *$ \\
\hline 9 & Kuttner (2001)-CH & 1989:6-2000:2 & SE & $0.27 *$ & $0.22 *$ & $0.20^{*}$ & $0.18 *$ & - & $0.10^{*}$ & 0.04 & 0.01 \\
\hline 10 & Poole et al. $(2002)^{\mathrm{e}}$ & 1994:3-2001:5 & SE & $0.74 *$ & $0.59 *$ & $0.52 *$ & 0.35 & - & 0.21 & 0.08 & -0.03 \\
\hline 11 & Poole et al. (2002) & 1987:8-1992:9 & SE & $0.80 *$ & $0.90 *$ & $0.92 *$ & $0.76^{*}$ & - & $0.57 *$ & $0.43^{*}$ & $0.28 *$ \\
\hline 12 & Swiston (2007) & 2000:3-2006:6 & SE & $0.52 *$ & $0.49 *$ & $0.44 *$ & $0.45 *$ & - & 0.27 & 0.23 & 0.06 \\
\hline
\end{tabular}

a An asterisk indicates that the coefficient is significant at the 0.05 level. This is applicable only to the single-equation (SE) studies.

${ }^{b}$ In this study confidence bands indicate significance of coefficient at all reported maturities.

c The Edeberg and Marshall estimates are from impulse response functions based on a seven-variable VAR estimated with monthly data.

$\mathrm{d}$ The Berument and Froyen estimates are from impulse response functions based on a 5 variable VAR estimated with weekly data.

e The "effect" reported in the table is given by the difference of 2 estimated coefficients $\left(\beta_{1}-\beta_{2}\right)$. The significance level refers to $\beta_{2}$ (see Poole et al., 2002, p. 71). 


\subsection{Some previous VAR results}

There is an extensive literature that measures monetary policy shocks as innovations in VARs. ${ }^{3}$ Evidence from this approach for the question at hand is provided in lines 4-7 of Table 1. A typical result is that in line 4 of Table 1 from Edelberg and Marshall (1996). Their results are based on impulse response functions from a seven-variable VAR estimated with monthly data from 1947 to 1995 . The estimated effects on longer-term rates from a change in the federal funds rate are smaller than those from the studies in lines 1-3 of the table. For maturities of 3 years or more these effects are small and at maturities of 10 years or more there are no significant effects. The findings in Evans and Marshall (1998) are similar. Based on a VAR analysis for the sample period 1964-1995 and employing three methods for identification of the system, they conclude that long-term rates are "virtually unaffected" by monetary policy actions.

Berument and Froyen (2006) estimate VARs with weekly data from 1975 to 2002 and consider various sub-periods. Estimated effects of changes in the federal funds rate on long-term interest rates from their study are shown in lines 5-7 of Table 1 . Looking at the longest time period (1975-2002), while the effect of a change in the federal funds rate on the 1-year interest rate is smaller, the effect on the long-term rate, as measured by the 10-year rate, is close to that of Edelberg and Marshall and Evans and Marshall. The Berument and Froyen (2006) VAR study for the period of the Greenspan chairmanship (Table 1, line 5) shows little significant effect of monetary policy actions on the 10 -year interest rate.

\subsection{Results from other studies}

Several other studies provide perspectives on the relationship between the federal funds rate and longer-term market interest rates.

Craine and Martin (2003) estimate a general factor model, which allows multiple sources of systematic risk, including monetary policy surprises, to affect long-term bond yields. They use daily data, as do the studies reported in lines 1-3, but use all observations instead of just those days on which policy shifts occurred. They summarize their findings as follows: "The yield curve response to a monetary surprise displays the classical textbook pattern-short maturity yields rise and long maturity yields do nothing." Their results suggest that the single-equation studies in lines 1-3 of Table 1 may overstate the effects of monetary surprises due to failure to control for other variables, which affect both the federal funds rate and longer-term rates.

Gurkaynak et al. (2005a) study the response of forward rates to changes in the federal funds rate, rather than the response of long-term yields. They find significant responses of forward rates out to 15 years. They use a single-equation approach but allow for the effects of other "surprise" announcements about macroeconomic variables. The pattern they find is that surprise increases in the federal funds rate, for example, will increase forward rates at horizons of up to 3-5 years but lead to a decline in forward rates at longer maturities, significantly so at maturities of 9-15 years. The Gurkaynak et al. (2005a) results are not entirely consistent with the studies reported in lines $1-3$ of Table 1 . The strong positive effects on long-term security yields out 30 years

\footnotetext{
${ }^{3}$ Christiano, Eichenbaum, and Evans (1999) summarize results from this research. For a critical view of this approach, see Rudebusch (1998). Kozicki and Tinsley (2001a, 2001b) study the linkage of monetary policy and short- and long-term interest rates within a VAR framework.
} 
in those studies are not consistent with the negative effects on forward rates beginning at 3-5 years found by Gurkaynak et al. Gurkaynak et al. (2006) repeat the analysis of Gurkaynak et al. (2005a) for the sample period January 1998 to March 2005. While the effect of monetary surprises is still significant for the 1-year nominal interest rate, this is not true for the 10-year rate. ${ }^{4}$

Poole, Rasche, and Thornton (2002) focus on a possible errors-in-variables problem in the estimation of the effects of unanticipated changes in the federal funds rate. For our purposes, the important feature of their results, from either OLS or the errors-in-variables procedure, is the difference across sub-periods of the 1988-2001 period. These sub-period estimates are shown in lines 10 and 11 of Table 1. [As in Kuttner (2001), unanticipated changes in the federal funds rate are measured using information from the federal funds futures market.] For the period 1987-1992 Poole et al. find evidence of significant effects of changes in the federal funds rate on interest rates at maturities out to 30 years. For the post-1993 sub-period, the estimated effects of changes in the federal funds rate on security yields are insignificant for maturities of 2 years or longer. Swiston (2007) in an update of Kuttner's study finds that unanticipated changes in the federal funds rate do not have significant effects on yields for maturities beyond 2 years for a sample of 2000-2006. These estimates are shown in Table 1, line 12.

\section{VAR estimates}

This section reports VAR estimates of the effects of monetary policy actions on longer-term interest rates. First, we document the difference between VAR estimates and results from theabove-cited studies employing single-equation specifications. Second, we show that estimated monetary policy effects on long-term interest rates based on VARs decline for the post-1987 period. For a period in the 1970s, previously examined by Cook and Hahn (1989), VAR and single-equation results are shown to be quite similar. Finally, estimates are presented in which the target federal funds rate replaces the actual rate.

\subsection{Details of the VAR specification}

The VARs that we estimate employ weekly data. The variables in the VARs are: the federal funds rate, one longer-term interest rate (1-year or 10-year), unemployment claims, economic activity, and commodity prices. Precise definitions of the variables together with data sources are provided in the footnote to Fig. 1. The non-interest rate variables are measured in natural logarithms. To choose the specification of the variables in the VARs, we examine the time series properties of those variables. The Dickey-Fuller, augmented Dickey-Fuller and Phillips-Perron tests fail to reject a unit root in the levels of these time series. Unit roots can, however, be rejected in first-differences of all series. We also tested for cointegration among the variables. For these tests there are two sets of VARs, one including each of the longer-term interest rates. Both Johansen's $\lambda$-max and $\lambda$-trace tests decisively reject the hypothesis of no cointegration for both sets of variables. Further tests indicate that there are most likely three or four cointegrating vectors in each set. If the variables in our system are nonstationary but cointegrated, Sims, Stock, and Watson (1990) and Lutkepohl and Reimers (1992) indicate that estimation of the

\footnotetext{
${ }^{4}$ Gurkaynak et al. (2006) also extend the empirical work to Sweden and the United Kingdom. Gurkaynak, Levin, Marder, and Swanson (2007) further extend the analysis to Canada and Chile.
} 

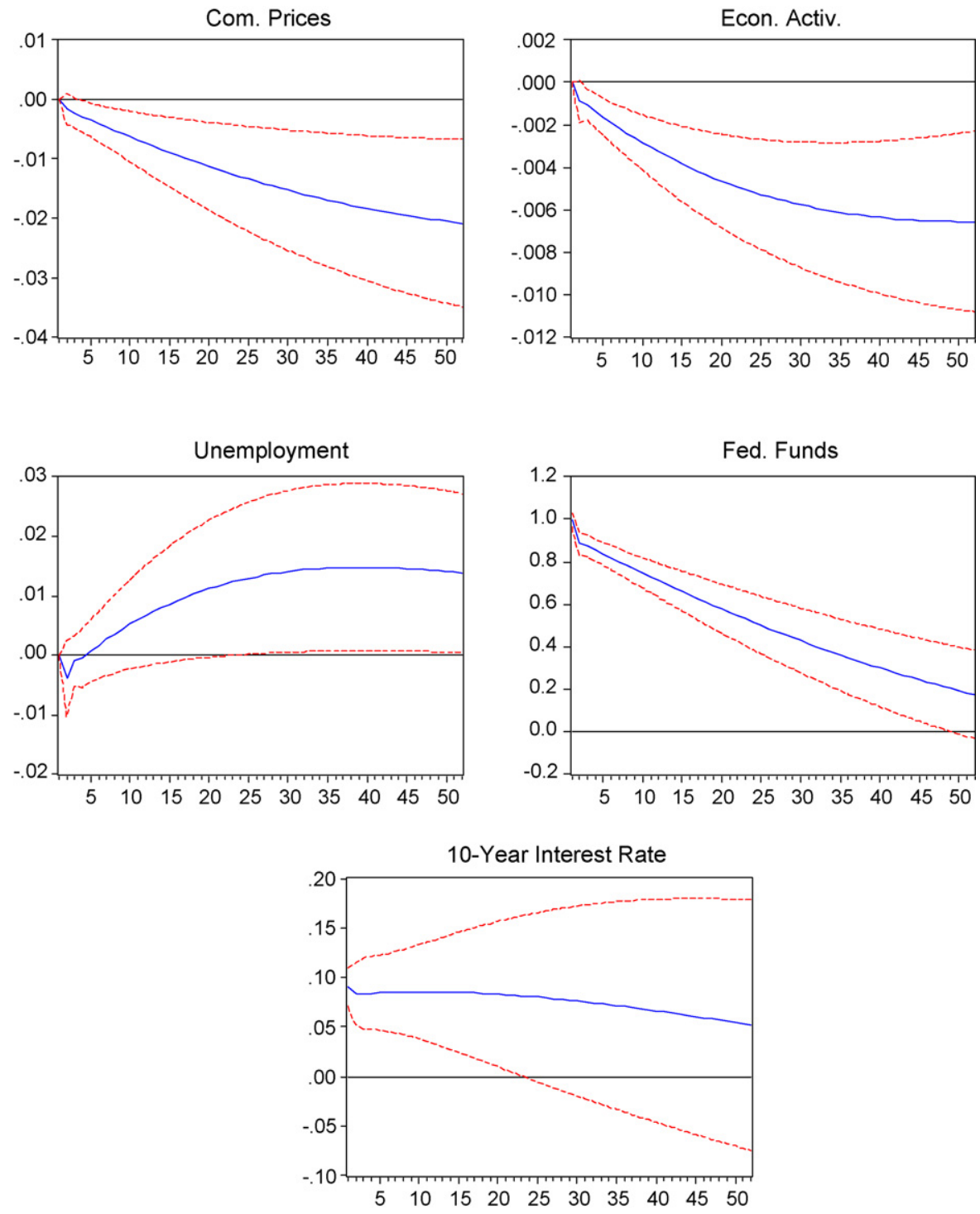

Fig. 1. Full-sample results (1971-2005); 10-year rate. ${ }^{5}$

VAR in (log) levels will provide consistent estimates. The Bayesian information criterion suggests a lag order of two for the VARs. We assume that the system is recursive and employ the Choleski decomposition for identification. The ordering of the variables is given in the footnote to Fig. 1.

\footnotetext{
5 Variable definitions and sources for the VARs are: the federal funds rate; a longer-term interest rate, either the 10or 1-year government security rate; an economic activity measure; an unemployment indicator; and a commodity price index. The federal funds rate (FF) is a weekly (Wednesday to Wednesday) average of daily data. The 1-year and 10-year interest rates $(R 1$ and $R 10)$ are constant maturity treasury rates, also weekly averages of Wednesday to Wednesday daily
} 


\subsection{Impulse response functions}

Impulse response functions are calculated to examine the effects on longer-term interest rates from innovations in the federal funds rate. We begin with impulse response functions based on VARs where the actual federal funds rate is the policy measure. Then, impulse response functions where the target federal funds rate is substituted as the policy measure are considered. In each case impulse response functions are calculated with the 1-year or, alternatively, the 10-year rate as a measure of the longer-term rate. To conserve space, the figures present only the impulse response functions for the 10-year rate.

Fig. 1 shows impulse response functions for 1971-2005. The impulse response functions are for a one-percentage point increase in the federal funds rate. The macroeconomic variables in the system all move in the expected directions. The 10-year rate rises initially by approximately 0.08 percentage points. The effects on the 10 -year rate persists for the 1 -year period for which the impulse response is calculated but is significant for only 24 weeks. The impulse response functions in which the longer-term interest rate is measured by the 1-year rate (not shown) indicate a larger initial response of approximately $0.28 \%$ points that is significant for 26 weeks. These estimated effects of VAR innovations are much smaller than those based on single-equation estimates of the effects of unanticipated changes in the federal funds rate in Table 1 (lines 1-3).

Those single-equation studies are, however, for a time period beginning in the mid-1980s. Impulse response functions from the same VARs on which Fig. 1 is based but for a roughly comparable period to the one used for the single-equation estimates are shown in Fig. 2. Here there is even less effect on the 10-year interest rate as a result of a one-percentage point increase in the federal funds rate. The initial effect is substantially smaller than for the 1971-2005 period and is insignificant. For the shorter recent period of 1994-2005, impulse response functions (not shown) indicate an even smaller and insignificant effect on the 10-year interest rate resulting from innovations in the federal funds rate.

Impulse response functions for the periods 1987-2005 and 1994-2005 based on VARs in which the longer-term interest rate is the 1-year interest rate also indicate a sharp fall off relative to the 1971-2005 period in the size and significance of the impact on that rate resulting from innovations in the federal funds rate.

\subsection{Further evidence from VARs}

Impulse response functions from VARs where policy actions are measured by innovations in the federal funds rate might understate policy effects due to a failure to filter out changes in the

\footnotetext{
rates. Interest rate data are from the Federal Reserve Bank of St. Louis. The measure of economic activity $(Y)$ is the weekly leading index compiled by the Economic Cycle Research Institute. The index is a composite of seven elements of the monthly index of leading economic indicators. It is released each Friday with data through the previous week. The unemployment measure (UN) is weekly new unemployment insurance claims (R539 Report CY, U.S. Department of Labor, week ending Saturday). The commodity price index (CP) is the Economist magazine index for all commodities (reported Saturday). We enter the variables in the following order: $\mathrm{CP}, \mathrm{Y}, \mathrm{UN}, \mathrm{FF},(R 10$ or $R 1)$. Theory suggests that on a weekly basis commodity prices, unemployment claims and our measure of economic activity are not affected by financial market variables. Each of these series is reported at approximately the same time of the week (Friday or Saturday) and the ordering among them reflects the assumption that commodity prices are not affected by contemporaneous shocks to real variables. This ordering reflects the assumption that the federal funds rate responds to current innovations in commodity prices, our measure of economic activity and unemployment claims. Longer-term interest rates are assumed to respond contemporaneously to the federal funds rate.
} 

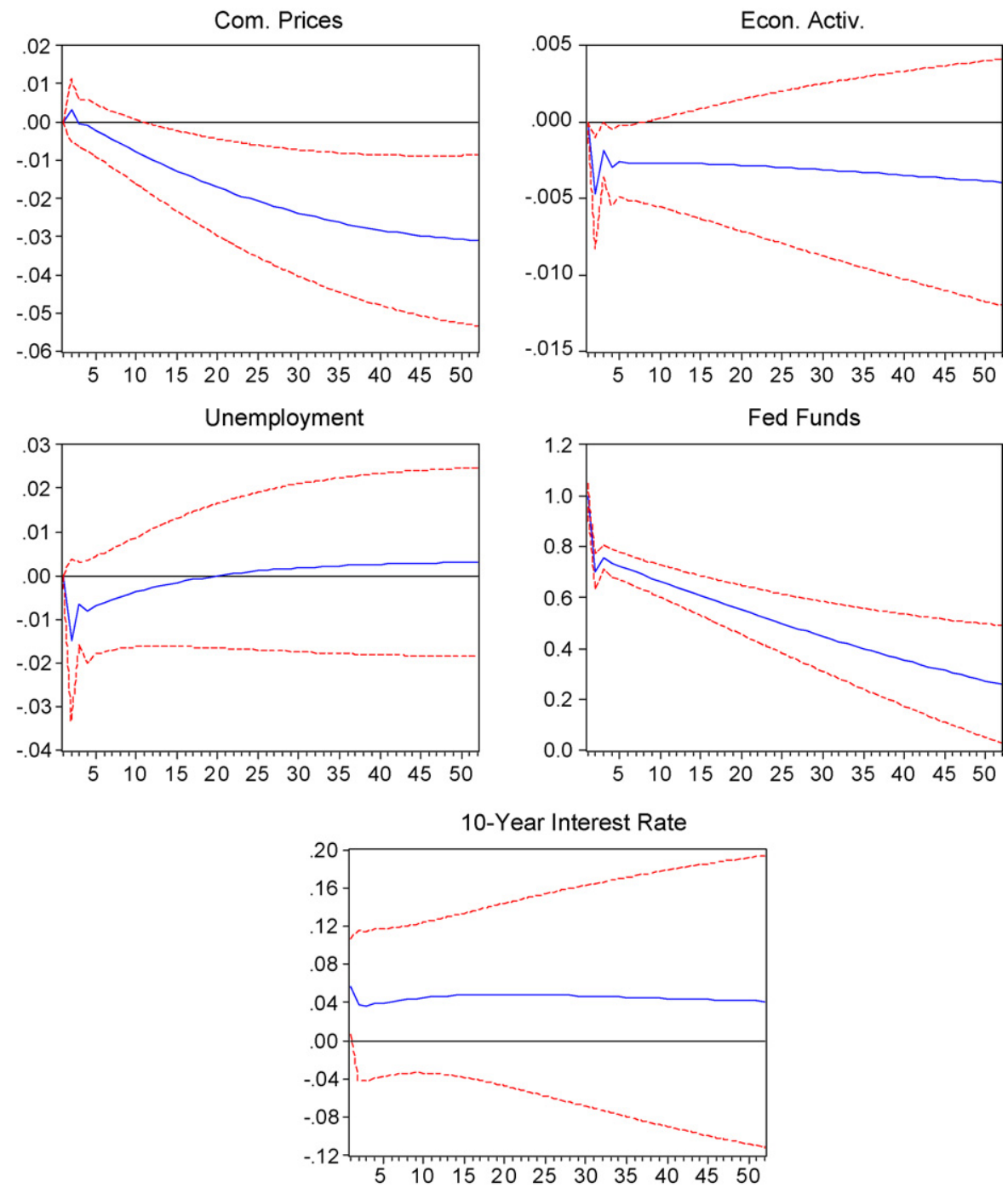

Fig. 2. Greenspan period (1987-2005); 10-year rate.

federal funds rate not caused by policy shifts. The substitution of the Federal Reserve's target federal funds rate in place of the actual federal funds rate provides a test of whether this distinction is important in explaining the divergence of conclusions drawn from single-equation studies and impulse responses from VARs. ${ }^{6}$

Fig. 3 shows impulse response function for the 1987-2005 period where the Federal Reserve's target federal funds rate (target) is the policy measure. The VARs on which these impulse response

\footnotetext{
${ }^{6}$ Data for the Federal Reserve's target federal funds rate are taken from Poole et al. (2002) for 1987-1993; from Ellingsen et al. (2004) for 1993-2002; and from the website of the Board of Governors of the Federal Reserve for 2002-2005.
} 

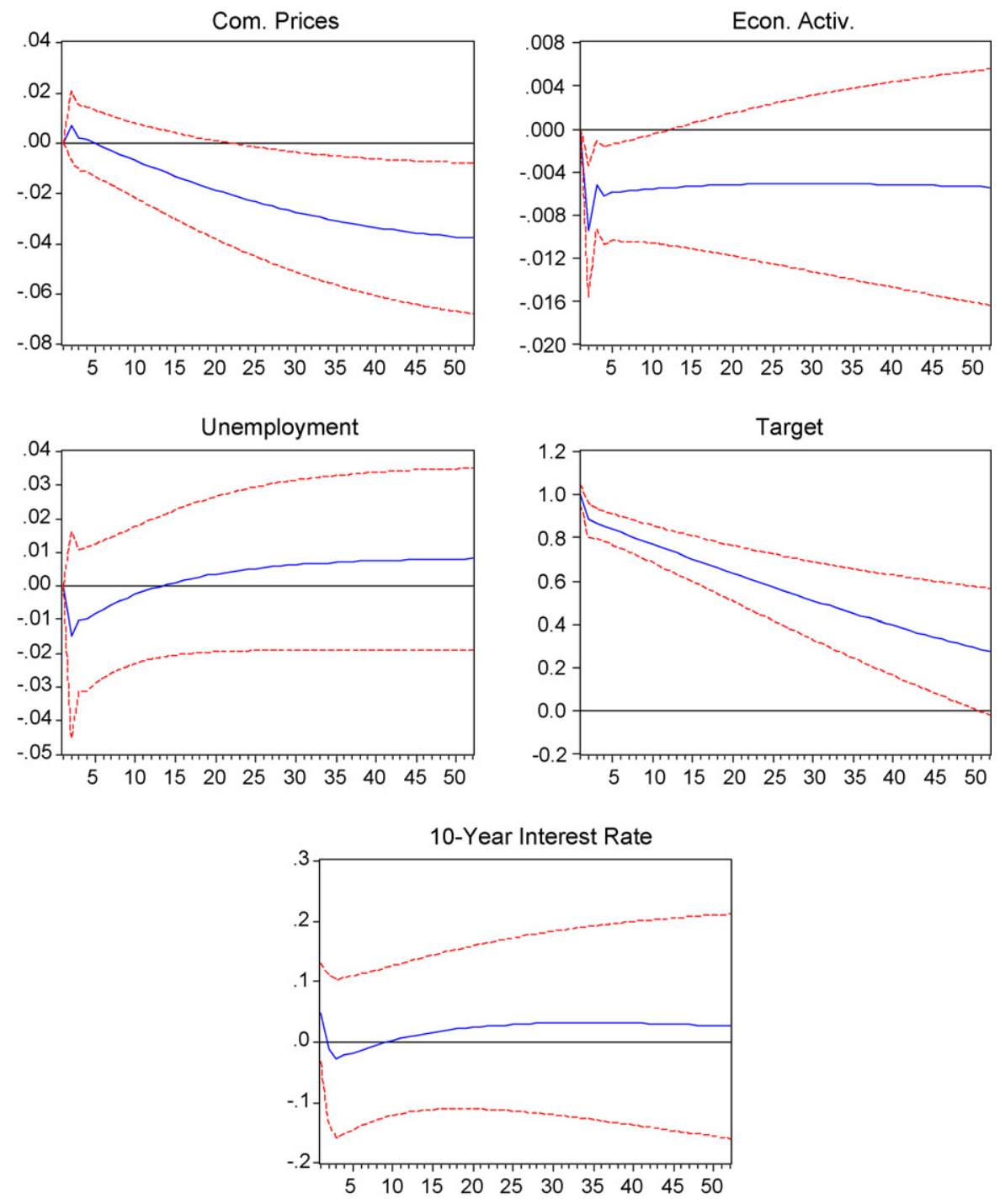

Fig. 3. Greenspan period (1987-2005); 10-year rate.

functions are based include the 10-year interest rate. As can be seen from the figure, innovations in the target rate have only small and insignificant estimated effects on the 10-year interest rate. Impulse response functions based on VARs including the 1-year rate with the target federal funds rate as the policy measure also show policy effects that are no greater than those with the actual federal funds rate as the policy measure.

A final VAR we report is for the period September 1974-1979 covered by Cook and Hahn (1989). The Cook and Hahn study is an off-cited source for the conventional view that a rise in the federal funds rate causes longer-term market interest rates to rise to an extent that diminishes 

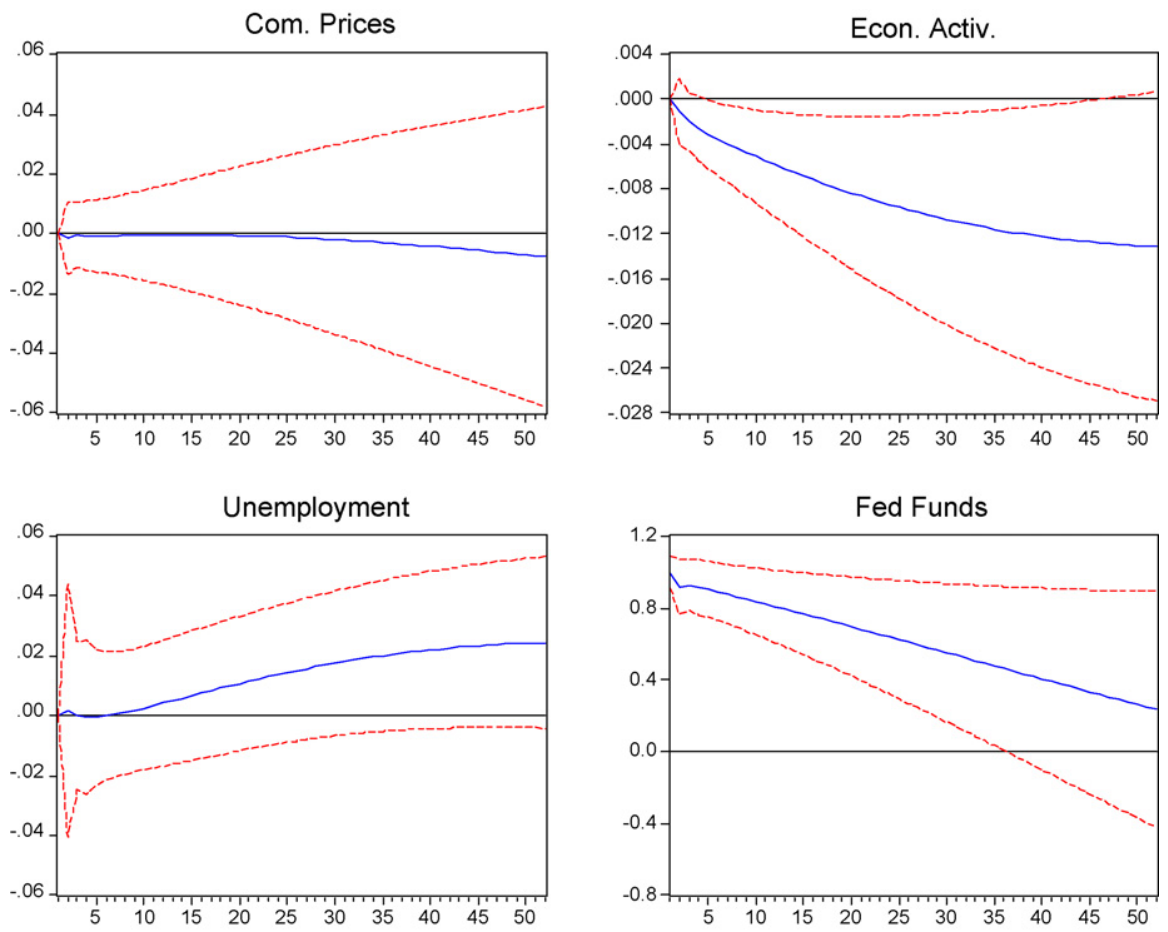

10-Year Interest Rate

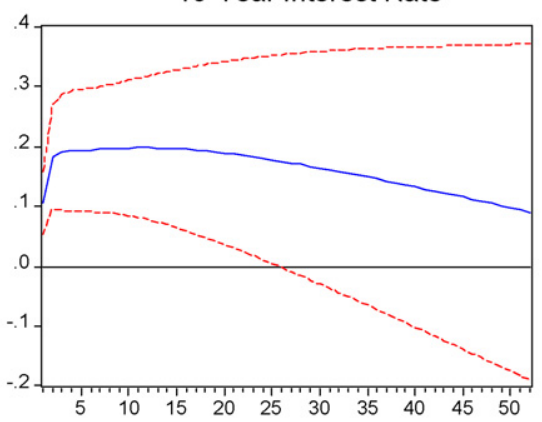

Fig. 4. Cook and Hahn period (1974:9-1979:9); 10-year rate.

with term to maturity. Cook and Hahn regressed changes in market interest rates on changes in the Federal Reserve's target for the federal funds rate. Results from their study are given in line 8 of Table 1.

Fig. 4 shows impulse response functions for the VARs we estimate for the Cook and Hahn sample period. The 10-year rate is the long-term interest rate. The results in the figures indicate that a one-percentage point increase in the federal funds rate would initially increase the 10-year interest rate by approximately 0.18 percentage points with a significant effect for about 6 months. The initial affect is somewhat above the Cook and Hahn estimate of $0.13 \%$ points. For this period from the 1970s both actual changes in the federal funds target rate and innovations from VARs 
appear to have contained substantial surprise components and therefore have affected longer-term interest rates. $^{7}$

Kuttner (2001) updated the Cook and Hahn study to the years 1989-2000 and found insignificant effects for changes in the Federal Reserve's target federal funds rate on the interest rates of securities with maturities greater than 5 years (Table 1; line 9). Swiston (2007, p. 5) finds "a continued deterioration in the response of yields to raw changes in the target federal funds rate" for the 2000-2006 period. The impulse response functions reported previously in this section show a corresponding fall off in the effects of innovations in the federal funds rate in the 1987-2005 period.

\section{Evidence based on reaction functions}

The finding that long-term interest rates exhibit sizable significant responses to changes in the federal funds rate is based on the single-equation studies (Table 1; lines 1-3). The question of the robustness of this evidence was raised in Section 1. In this section we examine the issue using federal funds reaction functions to decompose monetary policy actions into anticipated and unanticipated components. The reaction function approach allows us to consider a period back to the mid-1960s.

\subsection{Specification of the reaction function}

The reaction functions are of two forms: a forward-looking specification that employs the Federal Reserve's Green Book forecasts as well as data on relevant economic state variables and a specification that uses only the publicly available data.

The forward-looking reaction function we estimate is

$$
\mathrm{FF}_{t}=a_{0}+\sum_{i} A_{i}^{\prime} X_{t+i}^{*}+\sum_{i} B_{i}^{\prime} X_{t-i}+c_{1} \mathrm{FF}_{t-1}+c_{2} \mathrm{FF}_{t-2}+e_{t}
$$

The federal funds rate (FF) is regressed on: a vector of Green Book forecasts $\left(X^{*}\right)$ including forecasts of the inflation rate (CPI) the unemployment rate, and output (GDP or GNP) growth; real-time data $(X)$ for inflation $(\mathrm{CPI})$, the unemployment rate and industrial production; as well as two lagged values of the federal funds rate. The Green Book forecasts are for the current quarter and one and two quarters ahead $(i=0,1,2)$. The observations on the economic state variables are the most recently available observation and the two previous observations $(i=1,2,3$ or $i=2,3$, 4 ; depending on the day of the month on which the meeting took place).

Each observation is a FOMC meeting date; the real-time data are the most recent (and two lags) at that day of the month; the dependent variable is the average of the daily values of the federal funds rate from the date of a meeting $(t)$ until the date of the next meeting. ${ }^{8}$

The reaction function specification we estimate using only public information is of the same form as Eq. (1) with the forecast terms omitted. Because Green Book forecasts are released with a 5-year lag the public could not have actually used Eq. (1) to make forecasts of the federal funds

\footnotetext{
7 We show only the results from VARs that included the 10-year rate. Impulse response functions based on VARs including the 1-year interest rate show a similar pattern of results. Impulse response functions for both longer-term interest rates in which the target federal funds rate replaces the actual rate also show effects from VAR innovations at least as large as the Cook and Hahn (1989) single-equation estimates of the effects of target rate changes.

${ }^{8}$ Data sources for the reaction functions are provided in the data sources note to Table 2.
} 
rate. Still, much of the information used in those forecasts was available to the public. Our second reaction function specification thus probably understates the information available to the public while Eq. (1) overstates the information set. The two types of reaction functions are estimated for meeting dates beginning with 14 December, 1965 and ending with 19 December, 2000, a total of 348 meetings. ${ }^{9}$ We also consider several sub-periods.

\subsection{Long-term interest rate specifications}

To test for the effects of monetary policy on longer-term interest rates, we estimate the following specification, using the example of the one-year rate:

$$
R 1_{t}=\alpha_{0}+\beta_{1} \mathrm{FF}_{t}^{u}+\beta_{2} \mathrm{FF}_{t}^{a}+\beta_{3} R 1_{t-1}+\beta_{4} R 1_{t-2}+\Gamma^{\prime}\left(X_{t}-X_{t}^{*}\right)+\epsilon_{t}
$$

where $R 1$ is the 1 -year treasury security rate and $\mathrm{FF}^{u}$ and $\mathrm{FF}^{a}$ are the residuals and fitted values from the reaction functions given by Eq. (1), respectively. The equation also includes two lagged values of the 1-year rate. The last term before the residual requires explanation. This term is a coefficient vector $(\Gamma)$ multiplied by the vector of deviations of current values of the economic state variables included in Eq. (1) from their forecasted values. The generation of these forecasts is described below. Eq. (2) is estimated first without this term. The equation is then re-estimated including this term. The purpose is to test whether the effect of $\mathrm{FF}^{u}$ on the long-term interest rate is due to a failure to allow for the effects of other contemporaneous influences-the omitted variable problem referred to in Section 1. A specification analogous to Eq. (2) is estimated for the 10-year government security rate. Note that for both specifications the interval of estimation is that between FOMC meetings. Long-term rates are averages of daily rates over those intervals.

Before going on to examine results, notice how these estimates fit in to the literature in Table 1. Eq. (2) is a single equation. It differs from the single-equation studies in Table 1 in that the focus is on the meeting interval and on the unanticipated and anticipated components of the actual federal funds rate. The additional variables on the right-hand side also differentiate this equation from those in the other single-equation studies. Relative to VARs, when the Green Book forecasts are included, Eq. (2) clearly includes information not in those specifications. When those forecasts are excluded, Eq. (2) still differs from the monetary policy specification in the VAR studies in Table 1 in that: each observation is a meeting interval, real-time data is used and the data releases are timed so that some are from only a few days before the policy action.

\subsection{Estimation results}

Table 2 shows results for the case in which unanticipated and anticipated monetary policy measures are based on reaction functions that include the Green Book forecasts (as well as the real-time data). Table 3 provides results based on reaction functions that include only the lagged public information. ${ }^{10}$ The results reported in the Tables are those that included the deviation of

\footnotetext{
9 The end point was determined by data availability for the Green Book forecasts.

10 The reaction functions used to create the measure of monetary surprises and anticipated monetary policy actions were estimated in several ways. The reaction function estimates used to generate the monetary policy measures for Tables 2 and 3 entered the Greenbook forecasts as averages of the forecasted values for the current quarter and one and two quarters ahead. The economic state variables were entered as averages of the three most recent observations. The reaction functions were estimated separately for each time period covered in the Tables. Entering Greenbook forecasts of each period separately or entering separate lagged value of the state variables (in place of averages) did not result in large changes in our results.
} 
Table 2

Effect of the federal funds rate on longer-term interest rates: reaction functions using Green Book forecasts

\begin{tabular}{|c|c|c|c|c|c|c|}
\hline \multirow[t]{2}{*}{ Time period } & \multicolumn{3}{|l|}{ 1-Year rate } & \multicolumn{3}{|l|}{ 10-Year rate } \\
\hline & $\mathrm{FF}_{u}$ & $\mathrm{FF}_{a}$ & $R^{2}$ & $\overline{\mathrm{FF}_{u}}$ & $\mathrm{FF}_{a}$ & $R^{2}$ \\
\hline $12 / 14 / 1965-12 / 19 / 2000$ & $0.560(7.73)^{\mathrm{a}}$ & $0.125(3.06)$ & 0.973 & $0.192(4.26)$ & $0.034(2.42)$ & $\overline{0.978}$ \\
\hline $12 / 14 / 1965-9 / 18 / 1979$ & $0.534(8.05)$ & $0.096(3.34)$ & 0.962 & $0.202(5.07)$ & $0.017(1.94)$ & 0.976 \\
\hline $10 / 6 / 1979-12 / 19 / 2000$ & $0.592(5.16)$ & $0.308(4.06)$ & 0.972 & $0.156(2.25)$ & $0.058(2.21)$ & 0.974 \\
\hline 8/18/1987-12/19/2000 & $0.862(6.12)$ & $0.181(2.71)$ & 0.979 & $0.458(3.05)$ & $0.013(0.72)$ & 0.958 \\
\hline
\end{tabular}

Data sources: the data for the regressions reported in Tables 2 and 3 and for the reaction function estimates that are employed in these regressions are from the following sources: Interest rates are the federal funds rate and 1-year and 10-year constant-maturity treasure security rates taken from the Federal Reserve Bank of St. Louis data bank (FRED); the Federal Reserve Green Book forecasts are from the Federal Reserve Bank of Philadelphia data bank supplemented for earlier years from data provided by the Federal Reserve Bank of Boston. The real-time data on economic state variables are from the Federal Reserve Bank of Philadelphia data bank and from U.S. Department of Labor BLS data bank. The dates used to determine the most recently released data on the CPI are also from the BLS site.

${ }^{a}$ Numbers in parentheses are $t$-statistics, where standard errors are calculated with the robust standard errors formula.

Table 3

Effect of the federal funds rate on longer-term interest rates: reaction functions using only real-time data

\begin{tabular}{|c|c|c|c|c|c|c|}
\hline \multirow[t]{2}{*}{ Time period } & \multicolumn{3}{|l|}{ 1-Year rate } & \multicolumn{3}{|l|}{ 10-Year rate } \\
\hline & $\mathrm{FF}_{u}$ & $\mathrm{FF}_{a}$ & $R^{2}$ & $\mathrm{FF}_{u}$ & $\mathrm{FF}_{a}$ & $R^{2}$ \\
\hline $12 / 14 / 1965-12 / 19 / 2000$ & $0.580(8.26)^{\mathrm{a}}$ & $0.126(3.26)$ & 0.974 & $0.201(4.57)$ & $0.033(2.36)$ & 0.979 \\
\hline $12 / 14 / 1965-9 / 18 / 1979$ & $0.541(8.02)$ & $0.098(3.47)$ & 0.963 & $0.204(4.98)$ & $0.017(1.93)$ & 0.976 \\
\hline $10 / 6 / 1979-12 / 19 / 2000$ & $0.628(7.72)$ & $0.207(2.58)$ & 0.977 & $0.207(3.95)$ & $0.046(1.74)$ & 0.976 \\
\hline $8 / 18 / 1987-12 / 19 / 2000$ & $0.816(5.96)$ & $0.170(2.29)$ & 0.979 & $0.431(3.11)$ & $0.011(0.57)$ & 0.958 \\
\hline
\end{tabular}

${ }^{a}$ Numbers in parentheses are $t$-statistics, where standard errors are calculated with the robust standard errors formula.

current values of the economic state variables from their forecasted values $\Gamma\left(X_{t}-X_{t}^{*}\right) .{ }^{11} \mathrm{~A} F$-test on the joint significance of these variables show them to be significant for most specifications in the tables.

Effects of monetary surprises: for measures from both types of reaction functions, the estimates imply that an unanticipated one-percentage point change in the federal funds rate changes the 1year government security rate by between 0.53 and 0.63 percentage points for the whole period or either the pre- or post-October 1979 sub-period. For the 10-year rate the analogous range of estimates is 0.16-0.21. Comparing the pre- and post-1979 estimates, the impact of an unanticipated monetary policy action is somewhat larger in the later period in the case of the 1-year rate. For the 10-year rate whether the effect is larger or smaller in the post-1979 versus pre-1979 period differs depending on which type of reaction function is employed (Table 2 versus Table 3 ). When the Greenspan years are considered separately, the effects of unanticipated changes in the federal funds rate are considerably larger for both the 1-year and 10-year interest rates compared to the other estimates in the tables.

The estimates in the tables for the whole period as well as pre- and post-1979 sub-periods are within the range of estimates from single-equation studies as reported in Table 1. The estimates

\footnotetext{
11 The forecasts $\left(X_{t}^{*}\right)$ were generated as residuals from a regression of each state variable (industrial production, the CPI and unemployment rate) on 4 lags of the set of the three variables. These were rolling regressions estimated with 30 observations. Individual coefficients for these variables are not reported in the tables.
} 
from previous studies that are reported in Table 1 are for part of the Greenspan chairmanship. The estimates in Table 2 or 3 for the part of the Greenspan chairmanship for which we have data are on the high end of the studies in Table 1, close to those of Poole et al. (2002), line 11, for the earlier part of Greenspan tenure. ${ }^{12}$

Effects of anticipated policy actions: when the 1-year interest rate is the dependent variable, a number of the coefficients on the anticipated component of the federal funds rate are significant; for the 10-year rate these coefficients are small and some are insignificant. The significant coefficients for the case of the 1-year rate may result from the fact that our specification is in levels. The anticipated component of the federal funds rate reflects systematic movements in the level of short-term interest rates.

The estimates reported in this section show responses of long-term interest rates to unanticipated changes in the federal funds rate which are in line with results from other single-equation studies. Our estimates are based on a different measure of unanticipated monetary policy actions and are for a longer sample period than that examined in the single-equation studies reported in Table 1. We also attempt to correct for the influence of other variables on the long-term interest rate.

\section{Interpretation and conclusion}

The impulse response functions presented in Section 3 indicate that innovations in the federal funds rate from VARs have small and statistically insignificant effects on longer-term interest rates during the Greenspan chairmanship. The estimated effects are even smaller than those based on VAR estimates for the longer 1971-2005 period. Single-equation estimates of the effect of actual Federal Reserve target rate changes, Kuttner's (2001) estimates using the Cook and Hahn (1989) procedure, also indicate small effects during the Greenspan period. This is in contrast to the large and statistically significant estimated effects for unanticipated changes in the federal funds rate estimated from reaction functions at meeting intervals or in target rates as estimated by Kuttner (2001).

There is much less difference in estimates obtained using these different methods for pre-1979 sample periods. The larger difference in estimates for the post-1987 period is due to the fact that estimated monetary policy effects on long-term interest rates based on VARs or regressions using actual changes in the Federal Reserve's target federal funds rate decline when this sample period is examined. The effects of unanticipated changes in the federal funds rate based on reaction functions (Section 4) do not show a decline. The single-equation studies in lines 1-3 of Table 1 also show sizable and significant effects in the post-1987 period. This pattern of results is consistent with the view that neither innovations from VARs or changes in the actual Federal Reserve target federal funds rate successfully isolated "surprises" in monetary policy during the post-1987 period whereas they were more successful in doing so in the earlier period.

Lange, Sack, and Whitesell (2003) provide evidence that, in a gradual process, beginning in the later 1980s, markets did come to anticipate Federal Reserve actions to a greater extent. Prior to the late-1980s, they find market anticipations "largely contemporaneous." They see 1987-1994 as a transition period. Post-1994 "surprises" became less frequent. Poole (2005) documents changes in Federal Reserve procedures that may have further increased the predictability of changes in

\footnotetext{
12 The coefficients on the monetary surprise terms for the Greenspan chairmanship are also very close to Kuttner's (2001, p. 539) when he uses monthly data.
} 
the federal funds rate beginning in 1997. Many sources of information, including the Federal Reserve's own guidance to markets would not be incorporated in VARs. There is also evidence that as this process of greater predictability of Federal Reserve actions developed over the 1990s and after 2000, surprises become so infrequent that responses of long-term rates to them became hard to estimate. Gurkaynak et al. (2006) find that monetary surprises do not have a significant effect on the 10-year interest rate for the sample period 1998-2005, in contrast to the finding of Gurkaynak et al. (2005a), using the same methodology for the sample period 1990-2002. The estimates from Poole et al. (2002), line 10 of Table 1, show no significant effect of monetary surprises on interest rates with maturities beyond 1 year for the 1994-2001 period. Swiston finds no effect for monetary surprises in an update of Kuttner (2001) for the years 2000-2006. ${ }^{13}$

Our estimated effects of unanticipated policy actions on longer-term interest rates from reaction functions in Section 4 are for a longer period (1965-2000). For this period and for pre- and post-1979 sub-periods, the estimates indicate sizable significant effects on longer-term interest rates from monetary surprises. Whether the future will be like this extended period for which our measures indicate that there were often significant surprise components to Open Market Committee actions or like the more predictable past several years is not clear. The Federal Reserve currently makes a greater effort to be transparent but it can only signal its intentions. In uncertain times intentions may not prove to be good predictors of actions. Moreover, with a new chairman and many new members of the Board of Governors, post-2006 patterns of policy actions may be harder to predict than in the latter half of the nearly two decade Greenspan chairmanship.

\section{References}

Akhtar, M. A. (1995, January). Monetary policy and long-term interest rates: A survey of empirical literature. Contemporary Economic Policy, 13(1), 110-130.

Beechey, M. (2004). Excess sensitivity and volatility of long-term interest rates: The role of limited information in bond markets. Berkeley: University of California.

Beechey, M. (2007, March). A closer look at the sensitivity puzzle: The sensitivity of expected future short rates and term premia to macroeconomic news, finance and economic discussion series. Board of Governors of the Federal Reserve.

Berument, H., \& Froyen, R. (2006, December). Monetary policy and long-term U.S. interest rates. Journal of Macroeconomics, 28(4), 737-751.

Christiano, L. J., Eichenbaum, M., \& Evans, C. (1999). Monetary policy shocks: What have we learned and to what ends? In J. B. Taylor \& M. Woodford (Eds.), Handbook on macroeconomics (pp. 65-148). New York: Elsevier.

Cochrane, J. H., \& Piazzesi, M. (2002, May). The fed and interest rates-A high-frequency identification. American Economic Review, 92(2), 90-95.

Cook, T., \& Hahn, T. (1989, January). The effect of changes in the federal funds rate target on market interest rates in the 1970s. Journal of Monetary Economics, 24(1), 331-351.

Craine, R., \& Martin, V. (2003). Monetary policy shocks and security market responses. University of California Berkeley.

Edelberg, W., \& Marshall, D. (1996). Monetary policy shocks and long-term interest rates. Federal Reserve Bank of Chicago Economic Perspectives, 20, 2-17.

Ellingsen, T., \& Söderström, V. (2003). Why are long rates sensitive to monetary policy. Working paper, Stockholm School of Economics.

Ellingsen, T., Söderström, V., \& Masseng, L. (2004). Monetary policy and the bond market. Working paper.

Evans, C. L., \& Marshall, D. A. (1998). Monetary policy and the term structure of nominal interest rates: Evidence and theory. Carnegie Rochester Series on Public Policy, 49, 53-111.

\footnotetext{
13 The finding in these studies based on data for the most recent decade have led researchers to examine alternative measures of monetary surprises. Studies such as Gurkaynak (2005) and Gurkaynak, Sack, and Swanson (2005b) distinguish between short-term surprises that are considered here and long-term monetary surprises which come from the statements that accompany Open Market Committee actions.
} 
Gurkaynak, R. S. (2005). Using federal funds futures contracts for monetary policy analysis. Board of Governors of the Federal Reserve, Finance and Economics Discussion Series, \#2005-29.

Gurkaynak, R. S., Levin, A. T., \& Swanson, E. (2006). Does inflation targeting anchor long-run inflation expectations. Working paper.

Gurkaynak, R. S., Sack, B., \& Swanson, E. (2005a, March). The sensitivity of long-term interest rates to economic news: Evidence and implications for macroeconomic models. American Economic Review, 95(1), 425-436.

Gurkaynak, R. S., Sack, B., \& Swanson, E. (2005). Do actions speak louder than words? The response of asset prices to monetary policy actions and statements. International Journal of Central Banking, 1(1), 55-93.

Gurkaynak, R. S., Levin, A. T., Marder, A. N., \& Swanson, E. (2007). Inflation targeting and the anchoring of inflation expectations in the western hemisphere. Federal Reserve Bank of San Francisco Economic Review, 25-47.

Kozicki, S., \& Tinsley, P. A. (2001a, June). Shifting endpoints in the term structure of interest rates. Journal of Monetary Economics, 47(1), 613-652.

Kozicki, S., \& Tinsley, P. A. (2001b, January). Term structure views of monetary policy under alternative models of agents expectations. Journal of Economic Dynamics and Control, 25(1), 149-184.

Kuttner, K. N. (2001, June). Monetary policy surprises and interest rates: Evidence from the fed funds futures market. Journal of Monetary Economics, 47(3), 523-544.

Lange, J., Sack, B., \& Whitesell, W. (2003, December). Anticipations of monetary policy in financial markets. Journal of Money, Credit, and Banking, 35(6), 889-909.

Lutkepohl, H., \& Reimers, H. (1992, January). Impulse response analysis of cointegrated systems. Journal of Economic Dynamics and Control, 16(1), 53-78.

Poole, W. (2005, November/December). How predictable is fed policy. Federal Reserve Bank of St. Louis Review, 87(6), $659-668$.

Poole, W., Rashe, R. H., \& Thornton, D. L. (2002, July). Market anticipations of monetary policy actions. Federal Reserve Bank of St. Louis Review, 84(4), 65-94.

Roley, V., \& Sellon, G. H. (1995). Monetary policy actions and long-term interest rates. Federal Reserve Bank of Kansas City Review, 80(4), 75-89.

Romer, D. M. (2001). Advanced macroeconomics (2nd ed.). New York: McGraw Hall.

Romer, C., \& Romer, D. M. (2000, June). Federal Reserve information and the behavior of interest rates. American Economic Review, 90(3), 429-457.

Rudebusch, G. D. (1998). Do measures of monetary policy from VARs make sense. International Economic Review, 39(1), 907-931.

Sims, C. A., Stock, J. H., \& Watson, M. W. (1990, January). Inference in linear time series models with unit roots. Econometrica, 58(1), 113-144.

Swiston, A. (2007, July). Where have the monetary surprises gone? The effects of FOMC statements. IMF working paper. 